\title{
Arsenic in the Pearl River Delta and its related waterbody, South China: occurrence and sources, a review
}

\author{
Chen Luo ${ }^{1,2,3}$, Joyanto Routh ${ }^{1,2^{*}} \mathbb{D}$, Dinggui Luo², Lezhang Wei ${ }^{2}$ and Yu Liu²
}

\begin{abstract}
The Pearl River Delta (PRD) is a densely populated special economic zone in South China where rapid development since the late 1990s coincided with an increase of many environmental problems in recent years. One of these concerns is the high concentration of arsenic (As; up to $300 \mu \mathrm{g} / \mathrm{L}$ in groundwater) that has been documented in the PRD. Likewise, in surface water and soils, As levels are comparatively higher than in other places in China. Arsenic is discharged from various geogenic sources and anthropogenic activities along the river courses before it drains into the Pearl River Estuary. In general, relatively low As concentrations in the river are due to the limited input from weathering of parent rocks. In contrast, where mining is an important industry, As levels in the surroundings are higher, exceeding the national and international standards for drinking water and soil. The presence of sulfide ores and mining operations, such as extraction of heavy metals and disposal of mine tailings, are most likely responsible for the sharp increase of As above background levels in several tributaries draining into the Pearl River. Besides, in the middle and lower reaches of the tributaries, other anthropogenic sources, e.g., industrial effluents and domestic sewage discharge play an important role in increasing As levels. Finally, rice cultivated in the contaminated areas accumulates As and poses a health risk to the local people in the watershed.
\end{abstract}

Keywords: Arsenic sources, Geogenic, Anthropogenic, Water, Soil, Rice

\section{Introduction}

Arsenic (As) is a ubiquitous metalloid in nature. It is the 20th most abundant element in Earth's crust (Cullen and Reimer 1989; Henke 2009) and occurs in more than 240 different minerals in the environment, among which sulfides, sulfosalts, arsenates, and arsenites are the most common As-bearing minerals (Thornton and Farago 2012). Arsenic is widely used for producing alloys, batteries, glass, pesticides, textiles, and wood preservation (Gilhotra et al. 2018). Arsenic concentration in rocks ranges between $0.5-2.5 \mathrm{mg} / \mathrm{kg}$ (Thornton and Farago 2012); the world average concentration in soil is $6.83 \mathrm{mg} / \mathrm{kg}$

\footnotetext{
*Correspondence: joyanto.routh@liu.se

${ }^{1}$ Department of Thematic Studies-Environmental Change, Linköping University, 58183 Linköping, Sweden

Full list of author information is available at the end of the article
}

(Kabata-Pendias 2010). The global concentration of As in aquatic systems is variable. Average concentrations and/ or their ranges in natural waters reported are as follows: groundwater $(<0.50-10.0 \mu \mathrm{g} / \mathrm{L})$, river water $(0.83 \mu \mathrm{g} / \mathrm{L}$ in average, ranging between $0.13-2.10 \mu \mathrm{g} / \mathrm{L})$, lakes $(<0.06-$ $9.20 \mu \mathrm{g} / \mathrm{L}$ ), and open ocean $(1.00-3.70 \mu \mathrm{g} / \mathrm{L}$ ) (Smedley and Kinniburgh 2002 and references therein; Missimer et al. 2018). Because of the high toxicity associated with As (Smedley and Kinniburgh 2002; Kapaj et al. 2006), the United States Environmental Protection Agency (US EPA) and World Health Organization (WHO) suggest the provisional safe limit in drinking water as $10 \mu \mathrm{g} / \mathrm{L}$ (US EPA 2001; WHO 2003).

Arsenic contamination has been recorded and studied globally (Mandal and Suzuki 2002; Smedley and Kinniburgh 2002; Ng 2005; Kapaj et al. 2006; Chakraborty et al. 2015; Singh et al. 2015). Many countries, including 
Argentina, Bangladesh, Bolivia, Canada, Ghana, Hungary, India, Mexico, Nepal, Pakistan, Tanzania, Taiwan, USA, and Vietnam have all reported As contamination in the environment, which poses a serious challenge (Ali et al. 2019 and references therein). In China, arsenic contamination occurs in many provinces with different geological and geographical conditions (Guo et al. 2014), and mapping the As-prone areas has been an arduous task.

The Pearl River Delta (PRD) is a highly industrialized and densely populated region in South China. Accompanied by rapid industrialization, economic boom, and a sharp increase in population since the late 1990s, serious environmental concerns emerged in the PRD (Ye et al. 2012; Song et al. 2017). High As concentration $(>300 \mu \mathrm{g} / \mathrm{L})$ exceeding the national level in groundwater $(10 \mu \mathrm{g} / \mathrm{L}$ for Class III; $50 \mu \mathrm{g} / \mathrm{L}$ for Class IV and $\mathrm{V})$, soil (20-40 $\mathrm{mg} / \mathrm{kg}$ for agricultural soil), and surface water $(50 \mu \mathrm{g} / \mathrm{L}$ for Class I, II, and III) were reported by previous studies (Zhang et al. 2015a; Cui et al. 2018; Huang et al. 2018a; Zeng et al. 2019). Incidentally, the naturally high background levels of As along with humid climate intensifies both physical and chemical weathering processes and soil degradation, which further aggravates the problem in the PRD (Zhang et al. 2006). Arsenic released from minerals through this process is flushed into adjacent water bodies, settles in sediments, or is transported further downstream. In addition to inputs from natural sources or weathering processes, the anthropogenic contribution from industrial wastewater, burning of coal, and upstream mining operations are also suggested to be important sources of As contamination in the region (Huang et al. 2010; Wang et al. 2010). However, mining, by far, ranks on top in the PRD among different anthropogenic sources for contributing to the high As levels in the environment (Han et al. 2003). In China, non-ferrous As ore resources are unevenly distributed, with $>43 \%$ of the resources located in Guangxi and Yunnan provinces according to the national estimates of minerals (Chen et al. 2016). A number of these mines including those of $\mathrm{As}, \mathrm{Pb}-\mathrm{Zn}$, and other polymetallic ores are distributed across the Xijiang and Beijiang River basins. These mines are the major anthropogenic sources of As in surface water and sediments that reach the Pearl River further downstream (Luo et al. 2020; Ru et al. 2018; Wang et al. 2019a, b; Zhang et al. 2018). For example, it is suggested that about $42 \%$ of As in the Beijiang River originates from mine sites in its watershed; the Dabaoshan Mine Site is one of these major sources contributing to the As pool (Zhen et al. 2016). Water and sediment-borne As is transported downstream and it enters the Pearl River Estuary, surrounded by one of the most populated regions in China (Zhen et al. 2016). Hence, it is of vital importance to review the current pollution status of As in the PRD, identify the existing and potential sources of As input, and to investigate its implications on the local population. To the best of our knowledge, there is an absence of detailed information or review on the distribution or current status of As for this particular region in the country.

To fulfill the knowledge gap, this review summarizes (1) recent studies concerning the occurrence of As in groundwater, major river systems, and soils in the PRD; (2) As sources tracing back to the three major river basins in the PRD, in terms of geogenic and anthropogenic sources; (3) potential effects of high As, which pose a safety concern for food products, particularly, rice which is the staple food in this region. The review provides up-to-date information about the As contamination status in the PRD and its sources upstream, which sheds light on regional food and water safety issues, environmental management, and future studies. Keywords such as arsenic (As), Pearl River Delta, and Pearl River (and its tributaries) were used to screen peer-reviewed articles on Google Scholar. The search results were further limited by the publication year (2010-2020), the scope of research (environmental studies), and its prevalence in different media (groundwater, surface water, river water, soil, sediments, and rice); these articles were closely examined in writing this review.

\section{Study area}

Pearl River (ZhuJiang) is the second biggest river in China in terms of annual runoff (326 billion $\mathrm{m}^{3} /$ year; $\mathrm{Xu}$ et al. 2013), with 3 major tributaries, namely Xijiang River (West River), Beijiang River (North River), and Dongjiang River (East River). The sub-tropical and tropical monsoon climate brings abundant precipitation to the PRD during the rainy season (April to September). The mean annual temperature ranges from 14 to $22{ }^{\circ} \mathrm{C}$, and the mean annual precipitation ranges from 1200 to $2200 \mathrm{~mm}$ (Zhang et al. 2007, 2008). Runoff during the rainy season accounts for $\sim 80 \%$ of the total discharge into the river (Zhang et al. 2007). The alluvial plains in the downstream sections of the Pearl River are referred to as the PRD (Fig. 1). The Pearl River is the most complex water system in South China, with a catchment extending ca. $450,000 \mathrm{~km}^{2}$. The river drains into the South China Sea through eight major outlets in the PRD (Xu et al. 2013). The PRD includes Macau, Hong Kong, and 9 major cities in Guangdong Province (Dongguan, Foshan, Guangzhou, Huizhou, Jiangmen, Shenzhen, Zhaoqing, Zhongshan, and Zhuhai), 


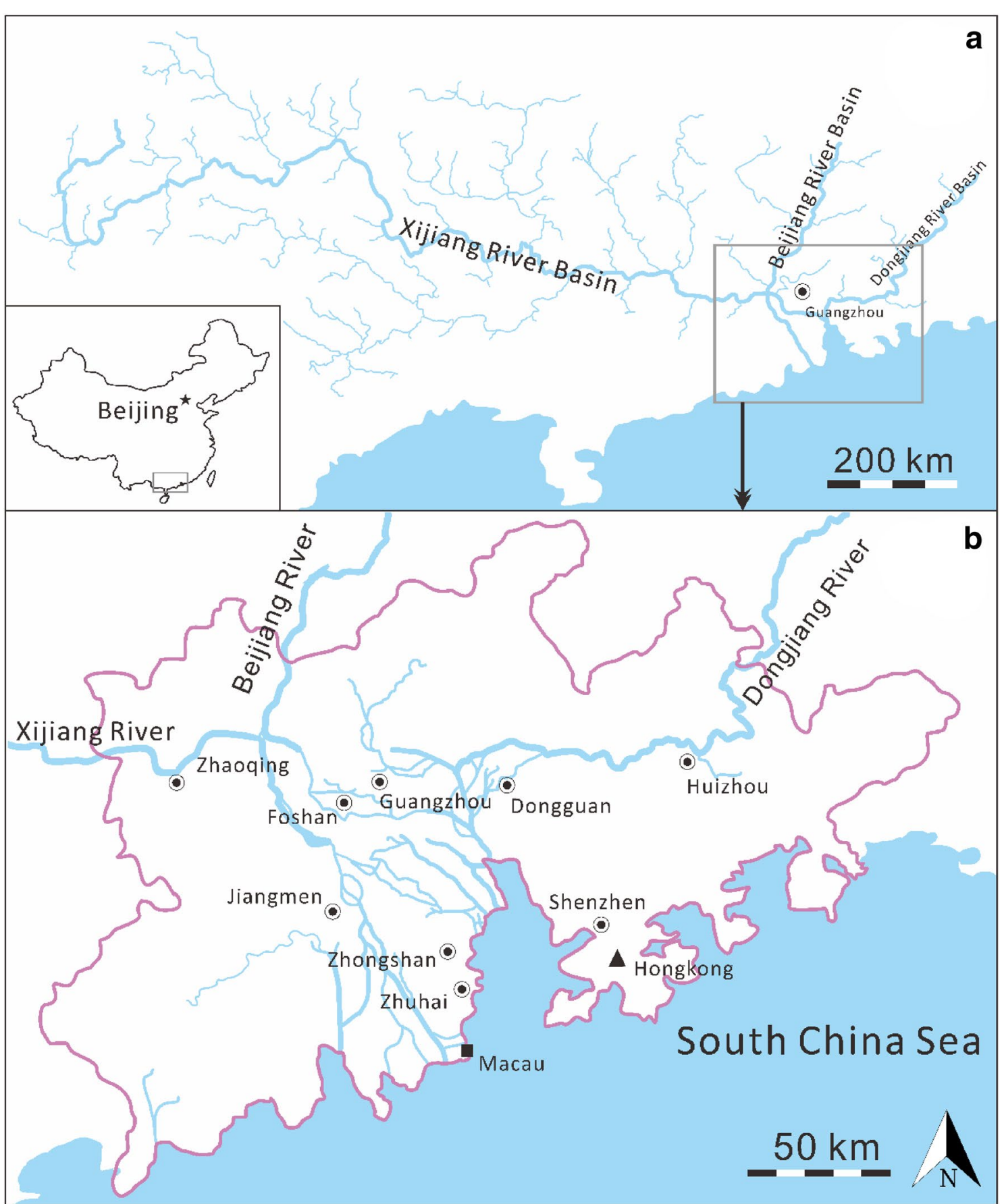

Fig. 1 The geographic setting for a the Pearl River and its tributaries' basins, and $\mathbf{b}$ the Pearl River Delta (modified from Xu and Han 2009)

with a total population of $>120$ million people (Vidal 2010). The Xijiang River, Beijiang River, and Dongjiang River basins were assumed to include all associated major water bodies upstream, as shown in Fig. 1. More detailed geographical distribution and origin of the smaller tributaries are described by Zhang et al. (2007). 


\section{Arsenic in the Pearl River Delta Sampling and analytical methods}

Sampling strategies and analytical methods used for the determination of As concentration vary, depending on the sample location/medium and the purposes of respective investigations. For groundwater, samples were usually collected from available/functional wells in the study area (Liu et al. 2014; Lu et al. 2016; Huang et al. 2013, 2018a). However, in certain cases, fresh boreholes were also drilled (Wang et al. 2012). For surface water, samples from different levels in the river (top, middle, and bottom) were collected and mixed to represent the water sample from one site ( $\mathrm{Li}$ et al. 2018; Zhen et al. 2016). Samples were then filtered through a $0.45-\mu \mathrm{m}$ membrane. Water samples were usually stored at $4{ }^{\circ} \mathrm{C}$ and acidified with $\mathrm{HNO}_{3}$ to $\mathrm{pH}<2$ before analysis (Huang et al. 2013, 2018a; Li et al. 2018; Wang et al. 2012). Sediment and soil samples were collected either from the surface (grab samples) or retrieved as profiles (cores) using soil borers or sediment corers. The samples were dried and passed through a 2-mm sieve and treated with $\mathrm{HNO}_{3}-\mathrm{HClO}_{4}$ acid for digestion (Cui et al. 2018; Li et al. 2017; Ye et al. 2012). Lin et al. (2018b) passed the samples through a 100-mesh sieve and digested them with $\mathrm{HNO}_{3}$ and $\mathrm{H}_{2} \mathrm{O}_{2}$, to remove the organic matter fraction from the soil since it interferes with analyses. Inductively coupled plasmamass spectrometry (ICP-MS) is most commonly used for measuring As. However, inductively coupled plasma optical emission spectrometry (ICP-OES) (Li et al. 2017), atomic absorption spectroscopy (AAS) (Ye et al. 2012; Zhen et al. 2016), and atomic fluorescence spectroscopy (AFS) (Lu et al. 2016) have also been used for determining As concentration.

\section{Arsenic in groundwater}

Arsenic concentration in groundwater varies widely across the PRD. Huang et al. (2018a) sampled groundwater from different types of aquifers throughout the region. In unconsolidated aquifers, As concentration was from ND to $303 \mu \mathrm{g} / \mathrm{L}$ (ND, not detectable); in fissure aquifer it was ND to $21.0 \mu \mathrm{g} / \mathrm{L}$; and in a karst aquifer it was ND to $0.25 \mu \mathrm{g} / \mathrm{L}$; the mean values in these aquifers were $5.00 \mu \mathrm{g} / \mathrm{L}, 1.00 \mu \mathrm{g} / \mathrm{L}$ and $0.40 \mu \mathrm{g} / \mathrm{L}$, respectively. Occurrences of high As levels are mostly found in unconsolidated aquifers in the Xijiang and Beijiang River delta (Huang et al. 2018a, b). Lu et al. (2016) observed that As concentration in shallow groundwater from Guangzhou and Zhuhai, sampled in March 2006, ranged from 0.05 to $4.30 \mu \mathrm{g} / \mathrm{L}$, with a median value of $0.69 \mu \mathrm{g} / \mathrm{L}$. Liu et al. (2014) sampled 85 domestic and abandoned wells in Guangzhou city in July 2006 and found As concentration from ND to $130 \mu \mathrm{g} / \mathrm{L}$, with a mean value of $4.24 \mu \mathrm{g} / \mathrm{L}$. In Dongguan, As level in samples, collected from 73 wells in July 2006, ranging from ND to $176 \mu \mathrm{g} / \mathrm{L}$, with a mean value of $7.60 \mu \mathrm{g} / \mathrm{L}$ (Huang et al. 2013). Wang et al. (2012) collected groundwater from 18 boreholes (depth ranging from 25 to $45 \mathrm{~m}$ ) in the central and southern part of the PRD during the dry season from 2007 to 2008. Groundwater in the basal aquifers contained relatively high concentrations of As (up to $161 \mu \mathrm{g} / \mathrm{L}$ ), and in aquifer sediments, As concentration ranged from 5.00 to $39.6 \mathrm{mg} / \mathrm{kg}$ (Wang et al. 2012). Although some local hotspots were observed in these studies mentioned above, the overall As level in groundwater is relatively low in general, with most of the observations below the limits specified for safe drinking water $(10 \mu \mathrm{g} / \mathrm{L})$ by the US EPA. Since groundwater in this region is hardly used as a drinking water resource in households (Hong et al. 2008; An et al. 2011), there is limited concern about the potential effect of As contamination on humans.

\section{Arsenic in surface water and sediments}

In a large-scale monitoring study covering the whole Pearl River Basin by Zhen et al. (2016), As concentration was reported to be around $2.09 \mu \mathrm{g} / \mathrm{L}$ in the Pearl River Estuary, $0.46 \mu \mathrm{g} / \mathrm{L}$ in Dongjiang River, $2.63 \mu \mathrm{g} / \mathrm{L}$ in Xijiang River, and $19.5 \mu \mathrm{g} / \mathrm{L}$ in Beijiang River. Similar results in the Beijiang River were reported by Song et al. (2011), whereas a lower range of concentration from 1.47 to $8.86 \mu \mathrm{g} / \mathrm{L}$ was reported by $\mathrm{Li}$ et al. (2018), with better quality control. The annual flux of As from 2006 to 2012 was reported to be $\sim 13.5$ tons/year from Dongjiang River, $\sim 45$ tons/year from Beijiang River, and 620 tons/ year from Xijiang River (Zhen et al. 2016). Metal flux during the wet season (April to September) accounted for $76 \%$ of the total As input (Zhen et al. 2016). In general, from 2006 to 2012, the annual metal flux, including that of As, has reduced steadily. Similarly, Han et al. (2019) concluded that As concentration in the PRD sediments has decreased from 2004 to 2012 and indicated an overall improvement in water quality. In particular, the suspended particulate matter (SPM) plays a crucial role in transporting heavy metals including As in the PRD (Ye et al. 2012). This is consistent with a recent study by Zeng et al (2019) who concluded that SPM in the Xijiang River carried a high concentration of As. Arsenic is one of the main contributors to the overall toxicity and poor water quality among different heavy elements such as $\mathrm{Cd}$, $\mathrm{Hg}, \mathrm{Pb}, \mathrm{Sb}, \mathrm{Se}$, and $\mathrm{Zn}$ carried by SPM in the tributaries (Zeng et al. 2019). A median concentration of $109 \mathrm{mg} /$ $\mathrm{kg}$ As which is 3 times higher than the world average has been reported from this region (Viers et al. 2009; Zeng et al. 2019).

Arsenic concentration in sediments ranged from 3.00 to $33.1 \mathrm{mg} / \mathrm{kg}$ in the estuary, $24.6-25.0 \mathrm{mg} / \mathrm{kg}$ in Guangzhou, $9.50-19.6 \mathrm{mg} / \mathrm{kg}$ in the Guangdong section, 
22.9-23.2 $\mathrm{mg} / \mathrm{kg}$ in the Pearl River Basin, and an average of $56.7 \mathrm{mg} / \mathrm{kg}$ in the mainstream of Pearl River (Han et al. 2019 and references therein). Arsenic concentration in sediments has decreased from 2004 to 2012. Strict regulation of waste water discharge dramatically lowered As released from ca. 141 tons in 2005 to 57 tons in 2014 (Han et al. 2019). Consistent with this trend, Ye et al. (2012) reported a steady decline in heavy metal accumulation from the mid-1990s onwards by analyzing sediment cores acquired from the Pearl River Estuary. From 1970 to 1990 , As increased rapidly from a low (26.7$28.8 \mathrm{mg} / \mathrm{kg}$ ) to a comparatively high level (35.8-76.5 mg/ $\mathrm{kg}$ ), corresponding to the rapid population growth and land-use changes in this region (Ye et al. 2012).

\section{Arsenic in soils}

Arsenic concentration in 298 agricultural soil samples collected across the PRD was analyzed and an average value of $11.6 \mathrm{mg} / \mathrm{kg}$ was reported by Lin et al. (2018b). Soil profiles collected from Hong Kong show a high variation of As concentration and ranged from 9.57 to $1986 \mathrm{mg} / \mathrm{kg}$ (Li et al. 2017) and 2.30 to $1510 \mathrm{mg} / \mathrm{kg}$ (Cui et al. 2018). The authors indicated that $\mathrm{As}(\mathrm{V})$ dominated (>98\%), and since it formed complexes with Fe oxides, there was limited potential for As to be released into the aqueous phase (Cui et al. 2018).

\section{Arsenic sources and controlling factors}

The background value of As in soil in the Guangdong Province ranged from 8.90 to $9.60 \mathrm{mg} / \mathrm{kg}$ (GPEMC 1990; Zhang et al. 2006), which is higher than the global average of $6.83 \mathrm{mg} / \mathrm{kg}$ (Kabata-Pendias 2010). The average concentration of As $(23.8 \mathrm{mg} / \mathrm{kg})$ in topsoil from the Xijiang River Basin (Guangxi Province section) was much higher than the PRD $(11.6 \mathrm{mg} / \mathrm{kg})$ and Yangtze River delta $(8.30 \mathrm{mg} / \mathrm{kg}$ ) (Liu et al. 2018). The relatively high background concentration of As in the PRD and Guangdong Province indicates a naturally high concentration of As from geogenic sources in this region (Zhang and Wang 2001) with additional inputs from anthropogenic sources that are further detailed below.

\section{Geogenic sources}

Granite is the dominant rock type (accounting for $>40 \%$ ) in Guangdong Province (along the Beijiang and Dongjiang River sections) (Zhang et al. 2006). Large outcrops of limestone and sandy-shale are widespread. In the southwest part of Guangdong Province (middle and lower reaches of the Xijiang River Basin), metamorphic and magmatic rocks (basalt) dominate (Fig. 2; Zhang et al. 2006; Xu and Han 2009). Intense precipitation during monsoon and enhanced weathering of parent rocks, increase the release of As multifold (Morin and Calas 2006) within the catchment. Besides, regional faults with NNE and NE-trend in the Guangdong Province, cut through the sandstone and sandy-shale rock types, intensifying weathering processes and release of As into groundwater (Zhang et al. 2006).

Arsenic concentrations in 260 soil samples across Guangdong Province ranged from 1.20 to $309 \mathrm{mg} / \mathrm{kg}$, 0.60 to $340 \mathrm{mg} / \mathrm{kg}$, and 1.30 to $255 \mathrm{mg} / \mathrm{kg}$, in the A, B, and C-horizons, respectively (Zhang et al. 2006). While most

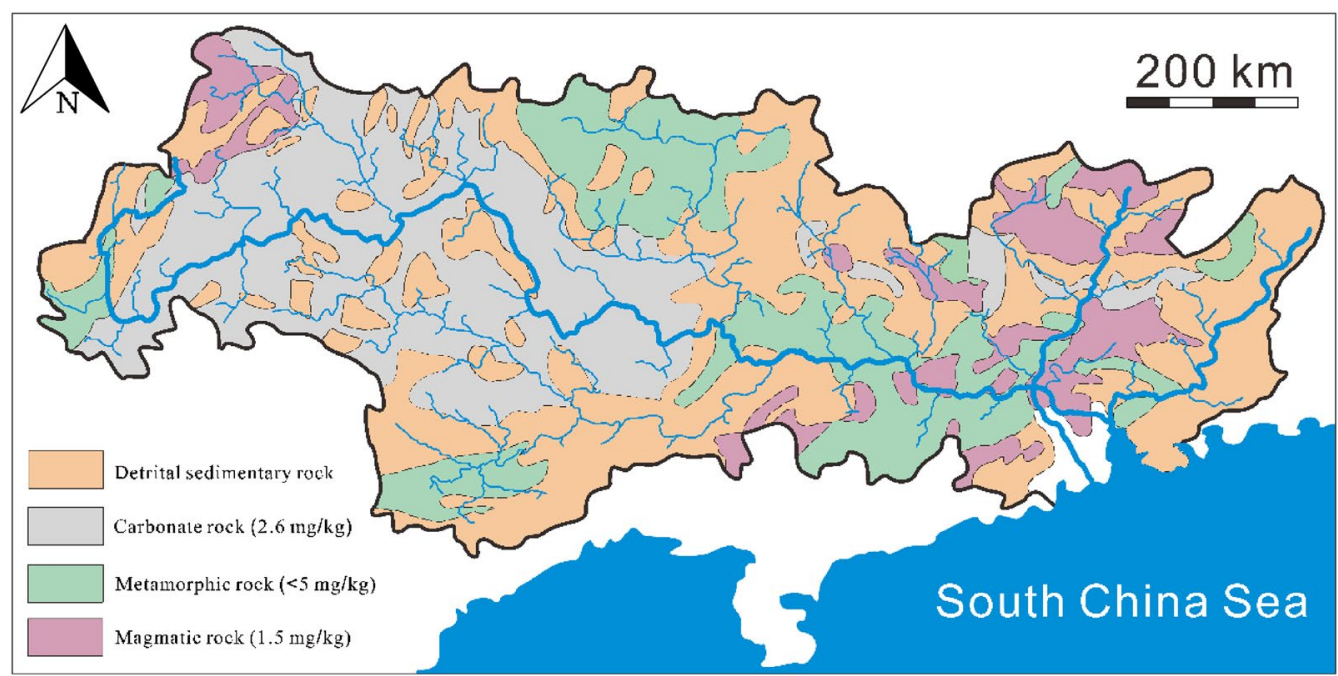

Fig. 2 Geologic map of parent rocks for the Pearl River Basin (modified from Xu and Han 2009). The global average concentration of arsenic in different parent rocks indicated by Smedley and Kinniburgh (2002) is used as a reference to provide an overview that does not necessarily pertain to a specific site in the Pearl River Delta 
sites had relatively low As concentrations, areas with high As content were mainly located where limestone and sandy-shale were the dominant parent rocks (Zhang et al. 2006). The upper Xijiang River is well-known for its karst landform (Zhang and Wang 2001), which affects the distribution of As. Hence, As is enriched in soil, sediment, and topsoil in the weathered carbonate watershed, which is attributed to the high weathering rate and formation of iron oxides and clay minerals (Qu et al. 2020). Arsenopyrite $(\mathrm{FeAsS})$ and arsenolite $\left(\mathrm{As}_{2} \mathrm{O}_{3}\right)$ were the major As-rich minerals and they are responsible for the high As content in soils (Zhang et al. 2006). Consistent with this, the red soil in South China, which forms from weathering of limestone, sandy-shale, and granite, contains a naturally higher concentration of As, and it takes longer for exogenous As (e.g., from mining activities) to settle into the more immobile and less bioavailable state (Wang et al. 2015). Red soil, lateritic red soil, and latosol are the common surface soil types in Guangdong Province accounting for $19.3 \%, 38.1 \%$, and $4.9 \%$, respectively, of the soil cover. These soils with low As adsorption capacity contribute to the leaching of As into groundwater (Guo et al. 2011; Lin et al. 2018a).

\section{Anthropogenic sources}

Rapid growth in the Chinese economy triggered a significant increase in mining leases for extracting various heavy metal(loid)s including As from the mineral-rich deposits (Shi et al. 2017). The rise was exponential and today China holds about a 50\% share of the global market for As-containing compounds and has been the single largest producer in the world since 2005 (Shi et al. 2017). Non-ferrous metal ores are the major sources of As, accounting for about $79 \%$ of the total As resources in China (Fig. 3). Mining of copper, lead, zinc, and coal contributes to $16 \%, 25 \%, 50 \%$, and $5 \%$, respectively, of total As produced in China (Shi et al. 2017). It is indicated that over $90 \%$ of the total input of As in the environment is due to the fact that oversupply of As-based products in the market has resulted in a low price, and therefore, it is not economically viable to extract As from different by-products of mining (e.g., mine tailings, slag, flue dust, and wastewater; Shi et al. 2017).

Hence, a significantly high concentration of aqueous As occurs close to the mine resulting from weathering of mine tailings, waste dumpsites, or slag (Fig. 4). As the contaminants travel downstream, sediments sequester As and other heavy metal(loid)s into the solid phase by adsorption, precipitation, and co-precipitation with secondary minerals (Chen et al. 2018; Luo et al. 2020). High $\mathrm{pH}$, abundant $\mathrm{CO}_{3}{ }^{2-}, \mathrm{HCO}_{3}{ }^{-}$, and $\mathrm{Ca}^{2+}$ ions generated from weathering of the karst terrain and carbonate dissolution promotes precipitation, and thereby, natural attenuation of As occurs in the environment ( $\mathrm{Ru}$ et al. 2018). These natural processes result in As concentration in most parts of these river basins remaining lower than the national and international standard for drinking

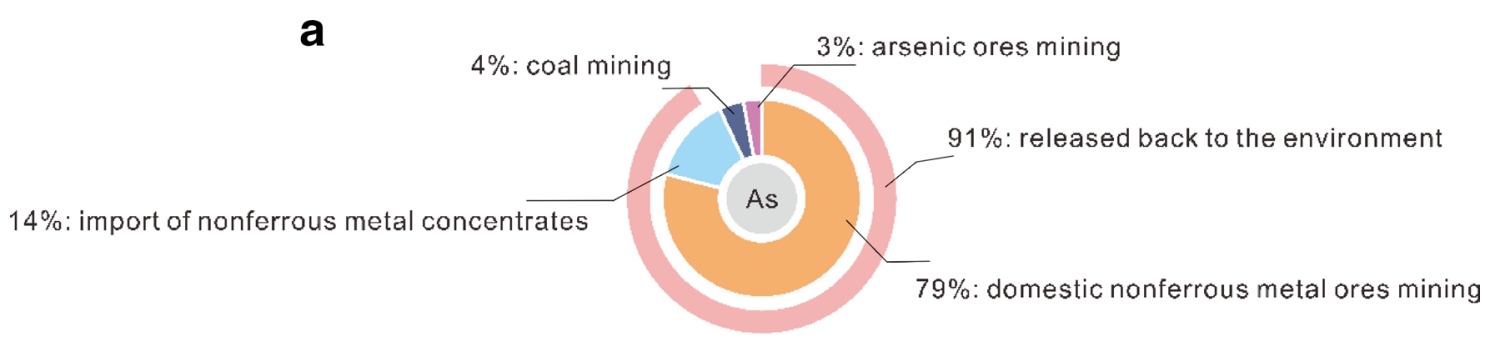

Total As input into China's anthroposphere and release to the environment

b

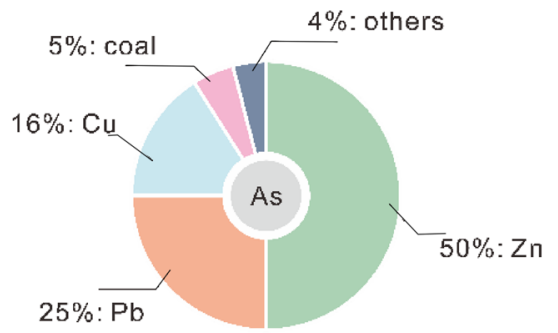

Contribution to total As mining in China

Fig. 3 Arsenic input and its sources in China a total input of As to the environment, and $\mathbf{b}$ contribution to the As pool from mining activities 


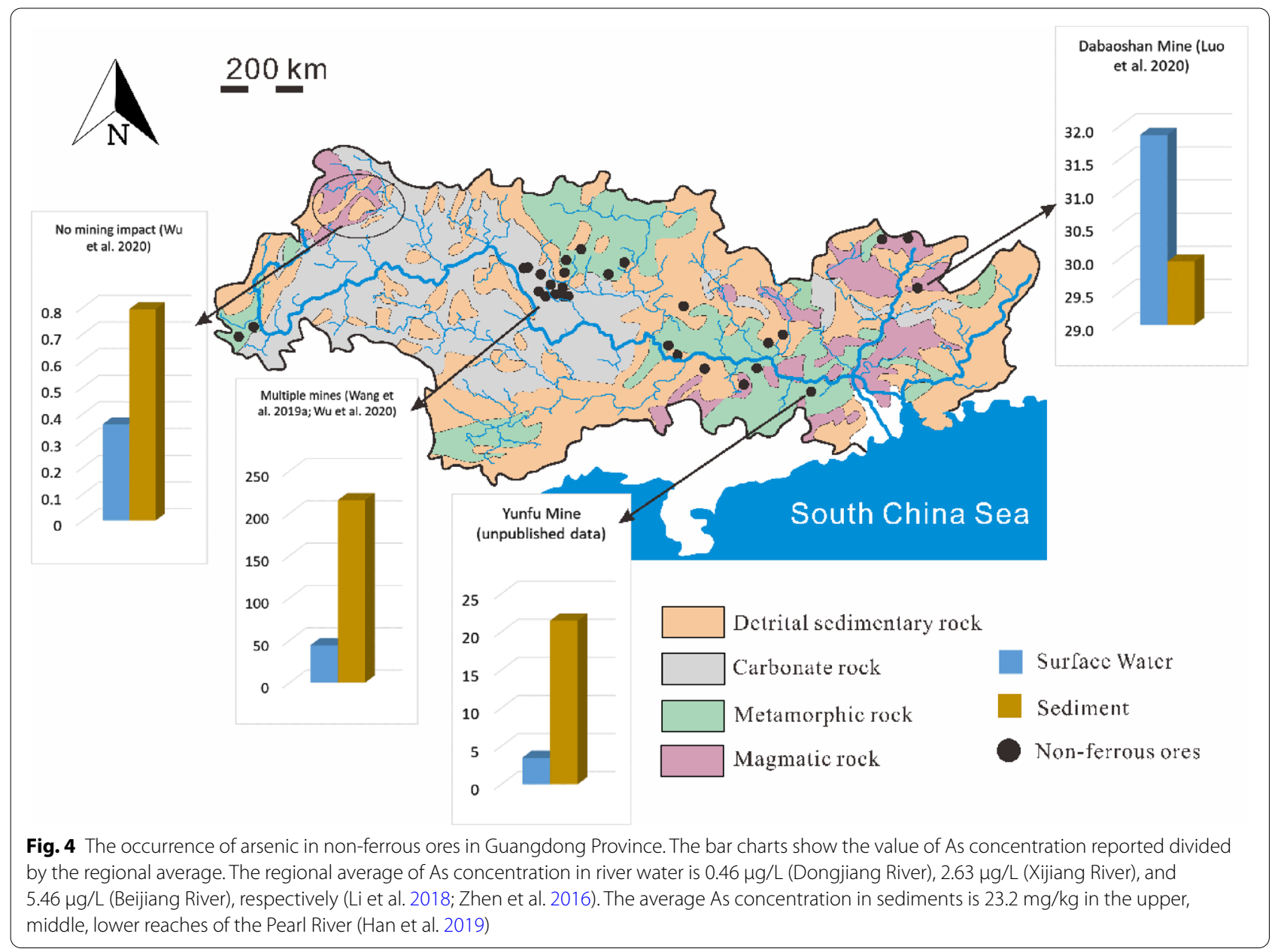

water $(10 \mu \mathrm{g} / \mathrm{L})$ except around the mines (WHO, 2003; GB 5749-2006).

However, in the lower reaches of Xijiang, Beijiang, and Dongjiang Rivers, and some parts of the PRD that are far from these mines, a slight increase in As concentration occurred downstream in sediments and surface waters. Zhuang et al. (2018) concluded that urbanization in these parts of the PRD was more likely to drive the observed high As levels. The contamination may be from industrial effluents and domestic sewage discharge (Yang et al.2017; Zhuang et al. 2018). The resulting heterogeneity observed in As concentrations in the PRD within the same section was probably due to the differences in anthropogenic activities in the basin (Han et al. 2019). Ye et al. (2012) observed higher As concentration in sediments close to the northwest coast of the Pearl River Estuary, whereas the low concentration in the southeast. A large number of pollutants from the Xijiang River and Beijiang River and other industrial sources located on the west coast contribute to the spatial differences.
Other major anthropogenic sources of As in the PRD are emissions derived from combusting coal in thermal power plants and extraction of metals from mineral ores (smelting and ore beneficiation processes). The annual emission of As in 2014 in Guangdong Province was 32.6 tons from industrial activities (Sha et al. 2019). The authors indicated that combustion of coal, non-ferrous metal processing and smelting, and iron and steel industry contributed to nearly $48 \%, 25 \%$, and $24 \%$ of As emissions, respectively (Sha et al. 2019). Arsenic emissions from coal combustion were comparable between the PRD and non-PRD regions in Guangdong Province. In contrast, $>90 \%$ of As emission from processing and smelting of non-ferrous metals and the iron and steel industry originated from the non-PRD region in Guangdong Province (Sha et al. 2019). The distinction in the provenance of emissions is unambiguously related to human activities in the basin. Furthermore, the atmospheric concentration of As from cities outside the PRD was considerably lower than the PRD itself (Duan and Tan 2013). It was suggested multiple factors affected 
the atmospheric transport of As such as precipitation, wind speed, and particle size. The high-altitude emission points in the non-PRD region enable atmospheric pollutants to travel over long distances before they are deposited (Zhang et al. 2015b; Sha et al. 2019). Atmospheric As concentration recorded in most major cities in Guangdong Province exceeded the Chinese national ambient air quality standard $\left(6 \mathrm{ng} / \mathrm{m}^{3}\right)$ and concentration $(6.6 \mathrm{ng} /$ $\mathrm{m}^{3}$ ) corresponding to an excess lifetime risk of 1:1,00,000 by the World Health Organization (WHO, 2000). PRD is among the areas with the highest atmospheric As concentration in China (Duan and Tan 2013), with $28.6 \mathrm{ng} / \mathrm{m}^{3}$ in Shenzhen, $31.8 \mathrm{ng} / \mathrm{m}^{3}$ in Zhaoqing (Yang et al. 2009), $39.2 \mathrm{ng} / \mathrm{m}^{3}$ in Guangzhou, and $96.9 \mathrm{ng} / \mathrm{m}^{3}$ in Foshan. The wet deposition was dominant during the rainy season due to high precipitation and low $\mathrm{PM}_{2.5}$ (particulate matter) levels in the air. In contrast, there was no variation in As levels for dry deposition throughout the year (Huang et al. 2018b). Inorganic As is the major species in atmospheric deposition of PM (Huang et al. 2018b). The proportion of As(III) depositing (with a mean of 50\%) is much higher than that carried by atmospheric particles (1-30\%). Huang et al. (2018b) suggested that this trend probably resulted from the transformation of $\mathrm{As}(\mathrm{V})$ to As(III) during the course of atmospheric transport and deposition of PM. Wet deposition transported a higher amount of As(III) species than during dry deposition because it was more soluble (Huang et al. 2018b).

\section{Controlling factors}

Both natural and anthropogenic processes play an important role in controlling the behavior of As in groundwater. Arsenic is released into groundwater mainly by reduction of $\mathrm{Fe} / \mathrm{Mn}$ oxyhydr(oxides) and decomposition and mineralization of organic matter (Huang et al. 2018a, b, 2014; Liu et al. 2014; Wang et al. 2012). Natural weathering of parent rocks is the main source of solid-phase As input (Wang and Jiao 2014). Liu et al. (2014) found that in the Guangzhou region groundwater lying close to the regional fault line had a significantly higher concentration of As. Sediments close to the fault line with low-permeability restrict groundwater from cycling and provide a reducing environment. It was also observed that a relatively slow recharge of surface water into porous aquifers characterized by low-lying topography provides a condition that favored reduction of Fe-hydroxides resulting in the As enrichment (Liu et al. 2014).

Huang et al. (2013) observed that groundwater hydrology in the river basins was controlled by the lateral flow from rivers and the network of irrigation channels in agricultural fields. Hence, the authors recommended that groundwater in unconsolidated aquifers near the river course should not be used for irrigation purposes since they could be contaminated. In contrast, groundwater from unconsolidated aquifers far from the river course could be safely used for irrigation. In urban areas, the input of As-bearing sewage discharge into the river had a limited effect because dilution reduces As concentration (Liu et al. 2014). In addition, the input of phosphate from sewage and agricultural fertilizers affected the distribution of As in groundwater because it competes with As. Likewise, nitrate altered the redox potential and limited the release of As (Liu et al. 2014).

To the southwest of the PRD, groundwater was mainly of $\mathrm{Na}-\mathrm{Cl}$ type, whereas in the northeast region, it was of $\mathrm{Ca}\left(\mathrm{HCO}_{3}\right)_{2}$ and $\mathrm{Na}\left(\mathrm{HCO}_{3}\right)$ type (Wang and Jiao 2012). The input of sulfate from the intrusion of seawater and its reduction, instead of oxidation, favored the formation of pyrites, which sequestered dissolved As by co-precipitation and controlled the ambient As levels (Wang et al. 2012; Huang et al. 2013). Besides seawater intrusion, the switchover to $\mathrm{Na}-\mathrm{Cl}$ type groundwater could also result from domestic sewage discharge and the application of chemical fertilizers (Huang et al. 2013). Huang et al. (2013) concluded that As in groundwater in Dongguan arose from urban centers where paper and printing industries were located. In addition, leachate from nearby landfills and direct discharge of wastewater containing a high concentration of As-contaminated surface water used for irrigation along the river course aggravated the problem (Huang et al. 2013). Besides, Ye et al. (2012) concluded that temporal change of As concentration in sediments was related to rapid urbanization since the 1990s; this was concomitant with land-use changes and population growth, which increased wastewater and sewage discharge. This assumption is supported by the emergence of $\mathrm{NO}_{3}{ }^{-}, \mathrm{SO}_{4}{ }^{-}$, and $\mathrm{Mg}^{2+}$-type groundwater observed between 1980 and 2006, which coincided with the local economic transformation to a manufacturingbased economy since the 1980s (Du et al. 2012; Huang et al. 2013).

Seasonal variation is considered to have a minor effect on As concentration in major fluvial tributaries and the PRD (Zhen et al. 2016). This trend, however, differs on a local scale and partly depends on land-use practices. For example, a large variation in As concentration was reported upstream close to the mines (Luo et al. 2020; Liu et al. 2018). The high concentration of As along with other heavy metals (cadmium, lead, zinc) during the rainy season resulted from the overflow of mine tailings, waste ponds, and/release from treatment plants as stormwater that discharges into the local fluvial outlets. Liu et al. (2018) suggested that it was mainly the floodwater that was responsible for transferring the heavy metal(loid)s to agricultural soils, resulting in significant contamination in the fields. Besides, Lin et al. (2018b) and Hu and Cheng 
(2016) concluded that agricultural practices (irrigation, deep tilling, and use of fertilizers) and natural occurrences in soils were the major sources of As. Hence, the flux of heavy metal input during the wet season (AprilSeptember) was much higher than the dry season coinciding with the variation in seasonal runoff (Zhen et al. 2016). Accompanied with dilution, greater runoff tends to bring a large amount of particulate matter, colloids, and humic material, which are important media for carrying As and other heavy metals (Yang et al.2017; Zeng et al. 2019). The contaminated material settled down in sediments in the Pearl River Estuary which serves as a sink (Zhen et al. 2016).

\section{Arsenic accumulation in rice}

The use of As-contaminated surface water and groundwater for irrigation is the major source of As in agricultural land (Ravenscroft et al. 2009). The uptake of As by plants poses a threat to human health mainly through ingestion (Peralta-Videa et al. 2009). Notably, rice is particularly vulnerable to As contamination (Meharg et al. 2008). In particular, food safety issues have aroused significant attention in the south, east, and southeast Asia, where rice is part of the staple diet in the food chain. The more mobile species, As(III), dominates in the paddy field, where reducing conditions favor the reduction of
$\operatorname{As}(\mathrm{V})$ to $\mathrm{As}(\mathrm{III})$. Cultivated on contaminated paddy soil, rice is observed to bioaccumulate high concentrations of As worldwide (Meharg et al. 2008).

The average As concentration in rice from China was $0.05 \mathrm{mg} / \mathrm{kg}$ (Fang et al. 2014), lower than $0.20 \mathrm{mg} / \mathrm{kg}$, which is the permissible limit according to the Food Safety Standard in China for rice (GB 2762-2017). Rice from Guangdong Province ranged from non-detectable values to $0.23 \mathrm{mg} / \mathrm{kg}$ and from 0.07 to $0.19 \mathrm{mg} /$ $\mathrm{kg}$ reported in two recent studies (Lin et al. 2015; Ma et al. 2017), with an average of $0.06 \mathrm{mg} / \mathrm{kg}$ and $0.11 \mathrm{mg} /$ $\mathrm{kg}$, respectively (Table 1 ). Arsenic concentration in rice grains from the PRD ranged between $0.13-0.28 \mathrm{mg} / \mathrm{kg}$ and $0.21-0.43 \mathrm{mg} / \mathrm{kg}$ from two different rice cultivars, with an average of $0.19 \mathrm{mg} / \mathrm{kg}$ and $0.29 \mathrm{mg} / \mathrm{kg}$, respectively ( $\mathrm{Lu}$ et al. 2010). Samples collected from paddy fields adjacent to mining areas (Ma et al. 2017), and those irrigated with surface water polluted by industrial wastewater (e.g., from an electronic waste dissembling industry; Lin et al. 2015) were affected. Consistent with these trends, rice grains from agricultural fields near the acid mine drainage-affected areas have higher As concentration in the province, with most samples exceeding the food safety threshold (Table 1). Thus, human activities play an important role in influencing the distribution of As in paddy soil and rice in the PRD.

Table 1 Arsenic concentration (mg/kg) in paddy soil and rice from mine-impacted paddy fields, Guangdong Province, and the Pearl River Delta

\begin{tabular}{|c|c|c|c|c|c|c|c|c|c|}
\hline & \multirow[t]{2}{*}{$n$} & \multirow[t]{2}{*}{ Soil } & \multicolumn{3}{|l|}{ Range } & \multicolumn{3}{|l|}{ Average } & \multirow[t]{2}{*}{ Literature } \\
\hline & & & Rice grain & Straw & Root & Rice grain & Straw & Root & \\
\hline Fankou mine & $20^{\mathrm{a}}$ & $10.2 \pm 4.20$ & $0.18-0.39$ & $1.60-6.90$ & $11.1-59.4$ & 0.25 & 3.30 & 25.6 & Li et al. (2014) \\
\hline Lechang mine & $8^{\mathrm{a}}$ & $80.8 \pm 25.9$ & $0.17-0.38$ & $2.10-10.4$ & $24.8-52.0$ & 0.28 & 5.80 & 35.0 & \\
\hline \multirow[t]{2}{*}{ Lianhuashan mine } & $73^{\mathrm{a}}$ & $77.7 \pm 25.7$ & $0.03-1.04$ & $1.11-12.7$ & $186-2136$ & 0.36 & 5.86 & 1003 & Liu et al. (2015) \\
\hline & $107^{\mathrm{a}}$ & 80.0 & $N D^{f}-1.00$ & $0.22-28.0$ & $40.0-2136$ & 0.32 & 3.00 & 822 & Yu et al. (2016) \\
\hline \multirow[t]{2}{*}{ Dabaoshan mine } & $16^{\mathrm{a}}$ & $176-279$ & - & - & - & 0.51 & 7.35 & 20.0 & Liao et al. (2016) \\
\hline & $95^{\mathrm{a}}$ & - & $0.07-0.45$ & - & - & 0.19 & - & - & Zhu et al. (2008) \\
\hline \multirow[t]{2}{*}{ Pearl River Delta } & $17^{c}$ & $13.7 \pm 12.8$ & $0.13-0.28$ & $0.93-6.19$ & $35.4-327$ & 0.19 & 3.70 & 99.0 & Lu et al. (2010) \\
\hline & $12^{d}$ & $10.2 \pm 6.30$ & $0.21-0.43$ & $1.66-18.0$ & $24.5-240$ & 0.29 & 5.74 & 102 & \\
\hline \multirow[t]{2}{*}{ Guangdong Province } & $41^{b}$ & - & $0.07-0.19$ & - & - & 0.11 & - & - & Ma et al. (2017) \\
\hline & $260^{b}$ & - & ND-0.23 & - & - & 0.06 & - & - & Lin et al. (2015) \\
\hline China & $92^{b}$ & - & ND-0.31 & - & - & 0.05 & - & - & Fang et al. (2014) \\
\hline Chinese standard & - & - & - & - & - & 0.20 & - & - & GB 2762-2017 \\
\hline \multirow[t]{2}{*}{ EU standard } & - & - & - & - & - & $0.25^{\mathrm{a}}$ & - & - & \multirow{2}{*}{$\begin{array}{l}\text { Commission } \\
\text { Regulation (EU) } \\
\text { 2015/1006 }\end{array}$} \\
\hline & - & - & - & - & - & $0.20^{b}$ & - & - & \\
\hline
\end{tabular}

\footnotetext{
a Unpolished (brown) rice,

b Polished (white) rice,

c Huahang-Simiao cultivar,

d Peizha-Taifeng cultivar,

e Threshold of contaminants in food, the Chinese national Standard for Food Safety (GB 2762-2017),

${ }^{f}$ Non-detectable value
} 
In the northern part of Guangdong Province, rice grains contained an average of $0.25 \mathrm{mg} / \mathrm{kg}$ and $0.28 \mathrm{mg} /$ $\mathrm{kg}$ As in paddy fields affected by the Fankou and Lechang $\mathrm{Pb}-\mathrm{Zn}$ mines (Table 1) (Li et al. 2014). The concentration in the paddy field was as high as $120 \mathrm{mg} / \mathrm{kg}$, which is 4 times China's soil environmental quality standard for agricultural land (20-30 mg/kg; GB 15618-2018). Arsenic concentration in paddy soil from the Lianhuashan tungsten mine (Liu et al. 2015) in eastern Guangdong Province, was up to $163 \mathrm{mg} / \mathrm{kg}$, which was more than 5 times higher than the specified safety limit. Likewise, in paddy fields, As concentration was up to $221 \mathrm{mg} / \mathrm{kg}$, which was 5 times the permissible limit for agricultural land in China. The average concentration of As in rice grains was $0.36 \mathrm{mg} / \mathrm{kg}$ and $0.32 \mathrm{mg} / \mathrm{kg}$ as reported by Liu et al. (2015) and Yu et al. (2016), respectively. Zhu et al. (2008) conducted a field survey in areas affected by the Dabaoshan Mine operation and found that the average As concentration was $0.19 \mathrm{mg} / \mathrm{kg}$ in rice. A more recent study, reported an average value of $0.51 \mathrm{mg} / \mathrm{kg}$ As around the Dabaoshan mine (Liao et al. 2016), which was more than 2.5 times the food safety standard (GB 2762-2017).

Arsenic concentration in rice varies depending on the different parts of the plants that are analyzed; As concentration indicated the following trend roots $>$ straw $>$ grain (Lu et al. 2010; Li et al. 2014; Liu et al. 2015; Liao et al. 2016; Yu et al. 2016). Inorganic As was the dominant species over organic arsenicals, and As(III) dominated over $\mathrm{As}(\mathrm{V})$. The concentration of $\mathrm{As}(\mathrm{III})$ in rice correlated with the total As levels. The ratio of As(III) to total As decreased with increasing total As levels, which probably resulted from the restricted accumulation and/ translocation within rice grains (Ma et al. 2017). Unpolished brown rice had a higher proportion of inorganic As and it is mostly located in the outer layer of the grain, whereas As in polished white rice is distributed more uniformly (Meharg et al. 2008). As(V) and phosphate share the same co-transporter. However, with a phosphorous deficiency in soils, iron-manganese plaque forms on the surface of the root and it acts as a mode for sequestering As (Meharg 2004). As(III) shares the same pathway with silicon through silicic acid transporter into the root zone, which is a highly efficient process (Ma and Yamaji 2008). It is reported that the presence of adequate phosphorus and silica, which are competitive elements, reduced adsorption of As in plants (Lu et al. 2010; Yu et al. 2016). Therefore, phosphorus and silica play an important role in influencing As levels in rice grains (Yu et al. 2016). Li et al. (2014) attributed the differences in uptake of As by rice to different $\mathrm{pH}$ levels, where the solubility of predominant As(III) species in paddy soil increased with a decrease in pH (Sahoo and Kim 2013). However, Li et al. (2014) argued that high As levels in rice around polluted mines did not result solely from the high As levels in soil; soil properties and biological processes also significantly affected As accumulation. It is the combined effects of desilicification, allitization (i.e., weathering under sub-tropical climate resulting in accumulation of Fe and $\mathrm{Al}$ ), deficiency of nutrients, and naturally high concentrations of As typical in different soil types in the study area that resulted in high As uptake in rice. Hence, remediation measures to mitigate the uptake of As and other heavy metals have been introduced which, include planting cash crops (sugarcane and mulberry) as part of crop rotation, introducing hyperaccumulators, biochar amendment, etc. (Chen et al. 2002; Qin et al. 2021). High As concentration in other parts of rice is also considered an indirect potential risk to humans since the husk and straw in the grain are usually used as feedstock for cattle and poultry, which may affect humans through the feedstock-meat-human pathway (Liao et al. 2016). Finally, atmospheric deposition of As, on the surface of plants, is also of concern and behooves detailed studies.

\section{Conclusions}

Arsenic is one of the most toxic and abundant metal(loid)s in sediments and surface water in the PRD. Arsenic in the study area mainly occurs from geogenic sources and it is stable and relatively immobile. However, As occurs in high concentrations in special settings and is significantly influenced by anthropogenic sources (in particular mining) in the upstream sections of the Pearl River Basin. In the lower reaches of the basin, other sources derived from industrial and sewage inputs influence the distribution of As. The Beijiang and Xijiang catchments have abundant non-ferrous and polymetallic ores and indicate high As levels in its catchment. The Beijiang River has the highest As concentration, whereas the Xijiang River has the largest flux of dissolved or SPM-borne As into the PRD. The Dongjiang River is of less concern due to the lack of mineral resources and low urbanization in its catchment. Effective measures should be taken to efficiently treat wastewater from mining activities, especially during the rainy season to reduce its transport downstream, which might have a positive effect on reducing the accumulation in agricultural soils and plants. It is crucial to assess the effectiveness of mine water treatment and the fate of pollutants for their high concentration and potential toxicity. Rice as a staple food in South China is particularly vulnerable to As contamination since rice from polluted areas has a higher concentration of As than those less affected by mining. Finally, to address the potential food and water safety issues induced by As contamination, more studies focusing on 


\section{the biogeochemical cycling of As from source to sink in the region are needed.}

\section{Acknowledgements}

We thank the anonymous reviewers for their suggestions which helped in improving the manuscript. This study was partly funded by Linkoping University-Guangzhou University Research Center on Urban Sustainable Development and the Natural Science Foundation of Guangdong Province, China (No. 2018A030310309).

\section{Authors' contributions}

$\mathrm{CL}$ and JR conceived and wrote the manuscript. LW, DL and LY reviewed/ edited the manuscript. All authors have read and approved the final manuscript.

\section{Funding}

Open access funding provided by Linköping University. This study was partly funded by Linkoping University-Guangzhou University Research Center on Urban Sustainable Development and the Natural Science Foundation of Guangdong Province, China (No. 2018A030310309).

\section{Availability of data and materials}

The review paper is based on inference drawn and assimilated from published data.

\section{Declarations}

\section{Competing interests}

There are no competing interests between the authors or with a public/private organization.

\section{Author details}

${ }^{1}$ Department of Thematic Studies-Environmental Change, Linköping University, 58183 Linköping, Sweden. ${ }^{2}$ Linköping University-Guangzhou University Research Center on Urban Sustainable Development, Guangzhou University, Guangzhou 510006, China. ${ }^{3}$ Department of Physics and Earth Sciences, Jacobs University Bremen, 28759 Bremen, Germany.

Received: 15 July 2020 Accepted: 23 March 2021

Published online: 01 April 2021

\section{References}

Ali W, Rasool A, Junaid M, Zhang H (2019) A comprehensive review on current status, mechanism, and possible sources of arsenic contamination in groundwater: a global perspective with prominence of Pakistan scenario. Environ Geochem Health 41:737-760. https://doi.org/10.1007/ s10653-018-0169-x

An T, Qiao M, Li G et al (2011) Distribution, sources, and potential toxicological significance of PAHs in drinking water sources within the Pearl River Delta. J Environ Monit 13:1457-1463. https://doi.org/10.1039/c0em0 0542h

Chakraborty M, Mukherjee A, Ahmed KM (2015) A review of groundwater arsenic in the Bengal Basin, Bangladesh and India: from source to sink. Curr Pollut Rep 1:220-247. https://doi.org/10.1007/s40726-015-0022-0

Chen T, Wei C, Huang Z et al (2002) Arsenic hyperaccumulator Pterisvittata L. and its arsenic accumulation. Chin Sci Bull 47:902-905. https://doi.org/10. 1360/02tb9202

Chen WQ, Shi YL, Wu SL, Zhu YG (2016) Anthropogenic arsenic cycles: a research framework and features. J Clean Prod 139:328-336. https://doi. org/10.1016/j.jclepro.2016.08.050

Chen M, Lu G, Wu J et al (2018) Migration and fate of metallic elements in a waste mud impoundment and affected river downstream: a case study in Dabaoshan Mine, South China. Ecotoxicol Environ Saf 164:474-483. https://doi.org/10.1016/j.ecoenv.2018.08.063

Cui J, li, Zhao Y ping, Li J shan, et al (2018) Speciation, mobilization, and bioaccessibility of arsenic in geogenic soil profile from Hong Kong. Environ Pollut 232:375-384. https://doi.org/10.1016/j.envpol.2017.09.040
Cullen WR, Reimer KJ (1989) Arsenic speciation in the environment. Chem Rev 89:713-764. https://doi.org/10.1021/cr00094a002

Du Y, Ge Y, Lakhan VC et al (2012) Comparison between CBR and CA methods for estimating land use change in Dongguan, China. J Geogr Sci 22:716-736. https://doi.org/10.1007/s11442-012-0958-6

Duan J, Tan J (2013) Atmospheric heavy metals and arsenic in China: situation, sources and control policies. Atmos Environ 74:93-101. https://doi.org/ 10.1016/j.atmosenv.2013.03.031

Fang Y, Sun X, Yang W et al (2014) Concentrations and health risks of lead, cadmium, arsenic, and mercury in rice and edible mushrooms in China. Food Chem 147:147-151. https://doi.org/10.1016/j.foodchem.2013.09.116

Gilhotra V, Das L, Sharma A et al (2018) Electrocoagulation technology for high strength arsenic wastewater: process optimization and mechanistic study. J Clean Prod 198:693-703. https://doi.org/10.1016/j.jclepro.2018. 07.023

Guo Z, Chai M, Zhan Z, Chen Z (2011) In: Spatiotemporal variation of soil pH in the past 30 years of Guangdong Province, China. 2011. 19th International conference on geoinformatics, geoinformatics. p. 1-5. https://doi.org/10. 1109/Geolnformatics.2011.5981168

Guo H, Wen D, Liu Z et al (2014) A review of high arsenic groundwater in Mainland and Taiwan, China: distribution, characteristics and geochemical processes. Appl Geochemistry 41:196-217. https://doi.org/10.1016/j. apgeochem.2013.12.016

Han FX, Su Y, Monts DL et al (2003) Assessment of global industrial-age anthropogenic arsenic contamination. Naturwissenschaften 90:395-401. https://doi.org/10.1007/s00114-003-0451-2

Han L, Gao B, Hao Het al (2019) Arsenic pollution of sediments in China: an assessment by geochemical baseline. Sci Total Environ 651:1983-1991. https://doi.org/10.1016/j.scitotenv.2018.09.381

Henke KR (2009) Arsenic in natural environments. In: Henke KR (ed) Arsenicenvironmental chemistry, health threats and waste treatment. Wiley, Chichester, pp 69-236

Hong HC, Wong MH, Mazumder A, Liang Y (2008) Trophic state, natural organic matter content, and disinfection by-product formation potential of six drinking water reservoirs in the Pearl River Delta, China. J Hydrol 359:164-173. https://doi.org/10.1016/j.jhydrol.2008.06.024

Hu Y, Cheng H (2016) A method for apportionment of natural and anthropogenic contributions to heavy metal loadings in the surface soils across large-scale regions. Environ Pollut 214:400-409. https://doi.org/10.1016/j. envpol.2016.04.028

Huang G, Sun J, Jing J, Zhang Y, Liu J, Wang J, Xiang X, Chen X, Cui H (2010) Distribution of arsenic in water and soil in the representative area of the Pearl River Delta. Acta Sci Nat Univ Sunyatseni 49:131-137 (in Chinese)

Huang G, Sun J, Zhang Y et al (2013) Impact of anthropogenic and natural processes on the evolution of groundwater chemistry in a rapidly urbanized coastal area, South China. Sci Total Environ 463-464:209-221. https://doi. org/10.1016/j.scitotenv.2013.05.078

Huang G, Chen Z, Liu F et al (2014) Impact of human activity and natural processes on groundwater arsenic in an urbanized area (South China) using multivariate statistical techniques. Environ Sci Pollut Res 21:13043-13054. https://doi.org/10.1007/s11356-014-3269-x

Huang G, Zhang M, Liu C et al (2018a) Heavy metal(loid)s and organic contaminants in groundwater in the Pearl River Delta that has undergone three decades of urbanization and industrialization: distributions, sources, and driving forces. Sci Total Environ 635:913-925. https://doi.org/10. 1016/j.scitotenv.2018.04.210

Huang M, Sun H, Liu H et al (2018b) Atmospheric arsenic deposition in the Pearl River Delta region, South China: influencing factors and speciation. Environ Sci Technol 52:2506-2516. https://doi.org/10.1021/acs.est.7b044 27

Kabata-Pendias A (2010) Trace elements in soils and plants, 4th edn. CRC Press, Boca Raton

Kapaj S, Peterson H, Liber K, Bhattacharya P (2006) Human health effects from chronic arsenic poisoning - a review. J Environ Sci Health Part A 41:2399-2428. https://doi.org/10.1080/10934520600873571

Li J, Dong F, Lu Y et al (2014) Mechanisms controlling arsenic uptake in rice grown in mining impacted regions in South China. PLoS ONE 9:e108300. https://doi.org/10.1371/journal.pone.0108300

Li JS, Beiyuan J, Tsang DCW et al (2017) Arsenic-containing soil from geogenic source in Hong Kong: leaching characteristics and stabilization/ 
solidification. Chemosphere 182:31-39. https://doi.org/10.1016/j.chemo sphere.2017.05.019

Li R, Tang C, Cao Y et al (2018) The distribution and partitioning of trace metals $(\mathrm{Pb}, \mathrm{Cd}, \mathrm{Cu}$, and $\mathrm{Zn})$ and metalloid (As) in the Beijiang river. Environ Monit Assess 190:399. https://doi.org/10.1007/s10661-018-6789-X

Liao J, Wen Z, Ru X et al (2016) Distribution and migration of heavy metals in soil and crops affected by acid mine drainage: public health implications in Guangdong province, China. Ecotoxicol Environ Saf 124:460-469. https://doi.org/10.1016/j.ecoenv.2015.11.023

Lin K, Lu S, Wang J, Yang Y (2015) The arsenic contamination of rice in Guangdong Province, the most economically dynamic provinces of China: arsenic speciation and its potential health risk. Environ Geochem Health 37:353-361. https://doi.org/10.1007/s10653-014-9652-1

Lin L, Zhou S, Huang Q et al (2018a) Capacity and mechanism of arsenic adsorption on red soil supplemented with ferromanganese oxide-biochar composites. Environ Sci Pollut Res 25:20116-20124. https://doi.org/ 10.1007/s11356-018-2188-7

Lin Y, Ma J, Zhang Z et al (2018b) Linkage between human population and trace elements in soils of the Pearl River Delta: implications for source identification and risk assessment. Sci Total Environ 610:944-950. https:// doi.org/10.1016/j.scitotenv.2017.08.147

Liu F, Huang G, Sun J et al (2014) Distribution of arsenic in shallow aquifers of Guangzhou region, China: natural and anthropogenic impacts. Water Qual Res J Can 49:354-371. https://doi.org/10.2166/warjc.2014.014

Liu C, Yu HY, Liu C et al (2015) Arsenic availability in rice from a mining area: Is amorphous iron oxide-bound arsenic a source or sink? Environ Pollut 199:95-101. https://doi.org/10.1016/j.envpol.2015.01.025

Liu Q, Chen B, Haderlein S et al (2018) Characteristics and environmental response of secondary minerals in AMD from Dabaoshan Mine, South China. Ecotoxicol Environ Saf 155:50-58. https://doi.org/10.1016/j.ecoenv. 2018.02.017

Lu Y, Dong F, Deacon C et al (2010) Arsenic accumulation and phosphorus status in two rice (Oryzasativa L.) cultivars surveyed from fields in South China. Environ Pollut 158:1536-1541. https://doi.org/10.1016/j.envpol. 2009.12.022

Lu Y, Tang C, Chen J, Yao H (2016) Assessment of major ions and heavy metals in groundwater: a case study from Guangzhou and Zhuhai of the Pearl River Delta, China. Front Earth Sci 10:340-351. https://doi.org/10.1007/ s11707-015-0513-8

Luo C, Routh J, Dario M et al (2020) Distribution and mobilization of heavy metals at an acid mine drainage affected region in South China, a postremediation study. Sci Total Environ. https://doi.org/10.1016/j.scitotenv. 2020.138122

Ma JF, Yamaji N (2008) Functions and transport of silicon in plants. Cell Mol Life Sci 65:3049-3057. https://doi.org/10.1007/s00018-008-7580-x

Ma L, Wang L, Tang J, Yang Z (2017) Arsenic speciation and heavy metal distribution in polished rice grown in Guangdong province, Southern China. Food Chem 233:110-116. https://doi.org/10.1016/j.foodchem. 2017.04.097

Mandal BK, Suzuki KT (2002) Arsenic round the world: a review. Talanta 58:201-235. https://doi.org/10.1016/S0039-9140(02)00268-0

Meharg AA (2004) Arsenic in rice-understanding a new disaster for SouthEast Asia. Trends Plant Sci 9:415-417. https://doi.org/10.1016/j.tplants. 2004.07.002

Meharg AA, Lombi E, Williams PN et al (2008) Speciation and localization of arsenic in white and brown rice grains. Environ Sci Technol 42:1051-1057. https://doi.org/10.1021/es702212p

Missimer TM, Teaf CM, Beeson WT et al (2018) Natural background and anthropogenic arsenic enrichment in Florida soils, surface water, and groundwater: a review with a discussion on public health risk. Int J Environ Res Public Health 15:2278. https://doi.org/10.3390/ijerph15102278

Morin G, Calas G (2006) Arsenic in soils, mine tailings, and former industrial sites. Elements 2:97-101. https://doi.org/10.2113/gselements.2.2.97

$\mathrm{Ng} \mathrm{JC} \mathrm{(2005)} \mathrm{Environmental} \mathrm{contamination} \mathrm{of} \mathrm{arsenic} \mathrm{and} \mathrm{its} \mathrm{toxicological}$ impact on humans. Environ Chem 2:146-160. https://doi.org/10.1071/ EN05062

Peralta-Videa JR, Lopez ML, Narayan M et al (2009) The biochemistry of environmental heavy metal uptake by plants: implications for the food chain. Int J Biochem Cell Biol 41:1665-1677. https://doi.org/10.1016/j.biocel. 2009.03.005
Qin J, Niu A, Liu Y, Lin C (2021) Arsenic in leafy vegetable plants grown on mine water-contaminated soils: uptake, human health risk and remedial effects of biochar. J Hazard Mater 402:123488. https://doi.org/10.1016/j. jhazmat.2020.123488

Qu S, Wu W, Nel W, Ji J (2020) The behavior of metals/metalloids during natural weathering: a systematic study of the mono-lithological watersheds in the upper Pearl River Basin. China Sci Total Environ 708:134572. https:// doi.org/10.1016/j.scitotenv.2019.134572

Ravenscroft P, Brammer H, Richards K (2009) Arsenic pollution. In: Ravenscroft P, Brammer H, Richards K (eds) A global synthesis. Wiley, Chichester

Ru X, Liao J, Liang L et al (2018) Quantification of the relationship between multiple metal(loid) distribution and integrated effect of internal-external factors in riverbed sediments across Xijiang River basin, South China. Sci Total Environ 643:527-538. https://doi.org/10.1016/j.scitotenv.2018. 06.236

Sahoo PK, Kim K (2013) A review of the arsenic concentration in paddy rice from the perspective of geoscience. Geosci J 17:107-122. https://doi.org/ $10.1007 /$ s12303-013-0004-4

Sha Q, Lu M, Huang Z et al (2019) Anthropogenic atmospheric toxic metals emission inventory and its spatial characteristics in Guangdong province, China. Sci Total Environ 670:1146-1158. https://doi.org/10.1016/j.scito tenv.2019.03.206

Shi YL, Chen WQ, Wu SL, Zhu YG (2017) Anthropogenic Cycles of arsenic in Mainland China: 1990-2010. Environ Sci Technol 51:1670-1678. https:// doi.org/10.1021/acs.est.6b01669

Singh R, Singh S, Parihar P et al (2015) Arsenic contamination, consequences and remediation techniques: a review. Ecotoxicol Environ Saf 112:247270. https://doi.org/10.1016/j.ecoenv.2014.10.009

Smedley PL, Kinniburgh DG (2002) A review of the source, behaviour and distribution of arsenic in natural waters. Appl Geochem 17:517-568. https:// doi.org/10.1016/S0883-2927(02)00018-5

Song MW, Huang P, Li F et al (2011) Water quality of a tributary of the Pearl River, the Beijiang, Southern China: implications from multivariate statistical analyses. Environ Monit Assess 172:589-603. https://doi.org/10.1007/ s10661-010-1358-y

Song C, He J, Wu L et al (2017) Health burden attributable to ambient PM2.5 in China. Environ Pollut 223:575-586. https://doi.org/10.1016/j.envpol. 2017.01.060

Viers J, Dupré B, Gaillardet J (2009) Chemical composition of suspended sediments in World Rivers: new insights from a new database. Sci Total Environ 407:853-868. https://doi.org/10.1016/j.scitotenv.2008.09.053

Wang Y, Jiao JJ (2012) Origin of groundwater salinity and hydrogeochemical processes in the confined quaternary aquifer of the Pearl River Delta, China. J Hydrol 438-439:112-124. https://doi.org/10.1016/j.jhydrol.2012. 03.008

Wang Y, Jiao JJ (2014) Multivariate statistical analyses on the enrichment of arsenic with different oxidation states in the Quaternary sediments of the Pearl River Delta, China. J Geochemical Explor 138:72-80. https://doi.org/ 10.1016/j.gexplo.2013.12.012

Wang S, Cao X, Lin C, Chen X (2010) Arsenic content and fractionation in the surface sediments of the Guangzhou section of the Pearl River in Southern China. J Hazard Mater 183:264-270. https://doi.org/10.1016/j. jhazmat.2010.07.020

Wang Y, Jiao JJ, Cherry JA (2012) Occurrence and geochemical behavior of arsenic in a coastal aquifer-aquitard system of the Pearl River Delta, China. Sci Total Environ 427-428:286-297. https://doi.org/10.1016/j.scito tenv.2012.04.006

Wang Y, Zeng X, Lu Y et al (2015) Effect of aging on the bioavailability and fractionation of arsenic in soils derived from five parent materials in a red soil region of Southern China. Environ Pollut 207:79-87. https://doi.org/ 10.1016/j.envpol.2015.08.033

Wang HB, Xu JM, Gomez MA et al (2019a) Arsenic concentration, speciation, and risk assessment in sediments of the Xijiang River basin. China. Environ Monit Assess 191:663. https://doi.org/10.1007/s10661-019-7883-4

Wang Y, Dong R, Zhou Y, Luo X (2019b) Characteristics of groundwater discharge to river and related heavy metal transportation in a mountain mining area of Dabaoshan, Southern China. Sci Total Environ 679:346358. https://doi.org/10.1016/j.scitotenv.2019.04.273

Xu Z, Han G (2009) Rare earth elements (REE) of dissolved and suspended loads in the Xijiang river, South China. Appl Geochemistry 24:1803-1816. https://doi.org/10.1016/j.apgeochem.2009.06.001 
Xu W, Yan W, Li X et al (2013) Antibiotics in riverine runoff of the Pearl River Delta and Pearl River ESTUARY, China: concentrations, mass loading and ecological risks. Environ Pollut 182:402-407. https://doi.org/10.1016/j. envpol.2013.08.004

Yang YJ, Wang YS, Wen TX, Zhao YN, Li J (2009) Element characteristics and sources of PM2. 5 at Mount Dinghu in 2006. Huan Jing Ke Xue 30:988-992 (in Chinese)

Ye F, Huang X, Zhang D et al (2012) Distribution of heavy metals in sediments of the Pearl River estuary, Southern China: implications for sources and historical changes. J Environ Sci 24:579-588. https://doi.org/10.1016/ S1001-0742(11)60783-3

Yu HY, Ding X, Li F et al (2016) The availabilities of arsenic and cadmium in rice paddy fields from a mining area: the role of soil extractable and plant silicon. Environ Pollut 215:258-265. https://doi.org/10.1016/j.envpol.2016. 04.008

Zeng J, Han G, Wu Q, Tang Y (2019) Heavy metals in suspended particulate matter of the Zhujiang river, southwest China: contents, sources, and health risks. Int J Environ Res Public Health 16:1843. https://doi.org/10. 3390/ijerph16101843

Zhang C, Wang L (2001) Multi-element geochemistry of sediments from the Pearl River system, China. Appl Geochemistry 16:1251-1259. https://doi. org/10.1016/S0883-2927(01)00007-5

Zhang HH, Yuan HX, Hu YG et al (2006) Spatial distribution and vertical variation of arsenic in Guangdong soil profiles, China. Environ Pollut 144:492-499. https://doi.org/10.1016/j.envpol.2006.01.029

Zhang SR, Lu XX, Higgitt DL et al (2007) Water chemistry of the Zhujiang (Pearl river): natural processes and anthropogenic influences. J Geophys Res Earth Surf 112:1-17. https://doi.org/10.1029/2006JF000493
Zhang S, Lu XX, Higgitt DL et al (2008) Recent changes of water discharge and sediment load in the Zhujiang (Pearl river) Basin, China. Glob Planet Change 60:365-380. https://doi.org/10.1016/j.gloplacha.2007.04.003

Zhang L, Guo S, Wu B (2015a) The source, spatial distribution and risk assessment of heavy metals in soil from the Pearl River Delta based on the National multi-purpose regional geochemical survey. PLoS ONE 10:e0132040. https://doi.org/10.1371/journal.pone.0132040

Zhang L, Wang S, Wang L et al (2015b) Updated emission inventories for speciated atmospheric mercury from anthropogenic sources in China. Environ Sci Technol 49:3185-3194. https://doi.org/10.1021/es504840m

Zhang J, Yan Q, Jiang J et al (2018) Distribution and risk assessment of heavy metals in river surface sediments of middle reach of Xijiang River basin, China. Hum Ecol Risk Assess 24:347-361. https://doi.org/10.1080/10807 039.2017 .1383850

Zhen G, Li Y, Tong Y et al (2016) Temporal variation and regional transfer of heavy metals in the Pearl (Zhujiang) river, China. Environ Sci Pollut Res 23:8410-8420. https://doi.org/10.1007/s11356-016-6077-7

Zhu YG, Sun GX, Lei M et al (2008) High percentage inorganic arsenic content of mining impacted and nonimpacted Chinese rice. Environ Sci Technol 42:5008-5013. https://doi.org/10.1021/es8001103

Zhuang Q, Li G, Liu Z (2018) Distribution, source and pollution level of heavy metals in river sediments from South China. CATENA 170:386-396. https://doi.org/10.1016/j.catena.2018.06.037

\section{Publisher's Note}

Springer Nature remains neutral with regard to jurisdictional claims in published maps and institutional affiliations.

\section{Submit your manuscript to a SpringerOpen ${ }^{\circ}$ journal and benefit from:}

- Convenient online submission

- Rigorous peer review

- Open access: articles freely available online

- High visibility within the field

- Retaining the copyright to your article

Submit your next manuscript at $\boldsymbol{\nabla}$ springeropen.com 